\title{
Anti-inflammatory Plant Flavonoids and Cellular Action Mechanisms
}

\author{
Hyun Pyo Kim ${ }^{1, *}$, Kun Ho Son ${ }^{2}$, Hyeun Wook Chang ${ }^{3}$, and Sam Sik Kang ${ }^{4}$ \\ ${ }^{1}$ College of Pharmacy, Kangwon National University, Chunchon 200-701, Korea \\ ${ }^{2}$ Department of Food and Nutrition, Andong National University, Andong 760-749, Korea \\ ${ }^{3}$ Collge of Pharmacy, Yeungnam University, Gyongsan 712-749, Korea \\ ${ }^{4}$ Natural Products Research Institute, Seoul National University, Seoul 110-460, Korea
}

Received September 6, 2004

\begin{abstract}
Plant flavonoids show anti-inflammatory activity in vitro and in vivo. Although not fully understood, several action mechanisms are proposed to explain in vivo anti-inflammatory action. One of the important mechanisms is an inhibition of eicosanoid generating enzymes including phospholipase $\mathrm{A}_{2}$, cyclooxygenases, and lipoxygenases, thereby reducing the concentrations of prostanoids and leukotrienes. Recent studies have also shown that certain flavonoids, especially flavone derivatives, express their anti-inflammatory activity at least in part by modulation of proinflammatory gene expression such as cyclooxygenase-2, inducible nitric oxide synthase, and several pivotal cytokines. Due to these unique action mechanisms and significant in vivo activity, flavonoids are considered to be reasonable candidates for new anti-inflammatory drugs. To clearly establish the therapeutic value in inflammatory disorders, in vivo anti-inflammatory activity, and action mechanism of varieties of flavonoids need to be further elucidated. This review summarizes the effect of flavonoids on eicosanoid and nitric oxide generating enzymes and the effect on expression of proinflammatory genes. In vivo anti-inflammatory activity is also discussed. As natural modulators of proinflammatory gene expression, certain flavonoids have a potential for new anti-inflammatory agents.
\end{abstract}

Keywords: flavonoid, inflammation, gene expression, phospholipase, cyclooxygenase

\section{Inflammation and flavonoids}

Inflammation is clinically defined as a pathophysiological process characterized by redness, edema, fever, pain, and loss of function. Although the currently used steroidal anti-inflammatory drugs (SAID) and nonsteroidal anti-inflammatory drugs (NSAID) treat acute inflammatory disorders, these conventional drugs have not been successful to cure chronic inflammatory disorders such as rheumatoid arthritis (RA) and atopic dermatitis (AD). Since the critical etiology and exacerbating mechanisms are not completely understood, it is difficult to develop a magic bullet for chronic inflammatory disorders. Therefore, there is a need for new and safe anti-inflammatory agents and one of the ongoing

*Corresponding author. FAX: +82-33-255-9271

E-mail: hpkim@kangwon.ac.kr

Invited article research candidates is plant constituents used in Chinese medicine.

Among many different groups of natural products, flavonoids, are a group of chemical entities of benzo- $\gamma$ pyrone derivatives widely distributed in the Plant Kingdom. They are mainly classified as chalcones, flavan-3-ols, flavanones, flavones and flavonols, isoflavones, and biflavonoids (Fig. 1). They have relatively simple chemical structures, but more than 4,000 derivatives have been reported from nature, indicating their chemical diversities.

Flavonoids, also known as nature's tender drugs, possess various biological/pharmacological activities including anticancer, antimicrobial, antiviral, antiinflammatory, immunomodulatory, and antithrombotic activities (1). Of these biological activities, the antiinflammatory capacity of flavonoids has long been utilized in Chinese medicine and the cosmetic industry as a form of crude plant extracts. Many investigations have proven that varieties of flavonoid molecules 
<smiles>O=C(/C=C/c1ccccc1)c1ccccc1</smiles>

Chalcone

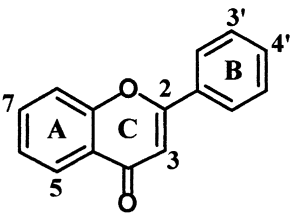

\begin{tabular}{lcccc}
\hline & 5 & 7 & $3^{\prime}$ & 4 \\
\hline Flavone & $\mathrm{H}$ & $\mathrm{H}$ & $\mathrm{H}$ & $\mathrm{H}$ \\
chrysin & $\mathrm{OH}$ & $\mathrm{OH}$ & $\mathrm{H}$ & $\mathrm{H}$ \\
apigenin & $\mathrm{OH}$ & $\mathrm{OH}$ & $\mathrm{H}$ & $\mathrm{OH}$ \\
luteolin & $\mathrm{OH}$ & $\mathrm{OH}$ & $\mathrm{OH}$ & $\mathrm{OH}$
\end{tabular}

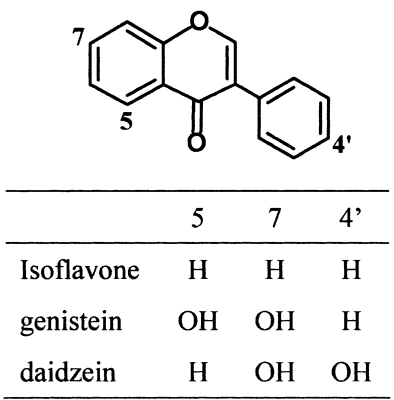<smiles>OC1=C(c2ccccc2)Oc2ccccc2C1</smiles>

Flavan-3-ol<smiles>COc1c(-c2cc(O)c(O)c(O)c2)oc2cc(O)cc(O)c2c1=O</smiles>

epigallocatechin-3-gallate (EGCG)<smiles></smiles>

\begin{tabular}{ccc}
\hline & 5 & 7 \\
\hline Flavanone & $\mathrm{H}$ & $\mathrm{H}$ \\
naringenin & $\mathrm{OH}$ & $\mathrm{OH}$ \\
\hline
\end{tabular}<smiles>O=c1c(O)c(-c2ccccc2)oc2ccccc12</smiles>

\begin{tabular}{lcccccc}
\hline & 5 & 7 & $2^{\prime}$ & $3^{\prime}$ & 4 & 5 \\
\hline Flavonol & $\mathrm{H}$ & $\mathrm{H}$ & $\mathrm{H}$ & $\mathrm{H}$ & $\mathrm{H}$ & $\mathrm{H}$ \\
galangin & $\mathrm{OH}$ & $\mathrm{OH}$ & $\mathrm{H}$ & $\mathrm{H}$ & $\mathrm{H}$ & $\mathrm{H}$ \\
kaempferol & $\mathrm{OH}$ & $\mathrm{OH}$ & $\mathrm{H}$ & $\mathrm{H}$ & $\mathrm{OH}$ & $\mathrm{H}$ \\
quercetin & $\mathrm{OH}$ & $\mathrm{OH}$ & $\mathrm{H}$ & $\mathrm{OH}$ & $\mathrm{OH}$ & $\mathrm{H}$ \\
morin & $\mathrm{OH}$ & $\mathrm{OH}$ & $\mathrm{OH}$ & $\mathrm{H}$ & $\mathrm{OH}$ & $\mathrm{H}$ \\
myricetin & $\mathrm{OH}$ & $\mathrm{OH}$ & $\mathrm{H}$ & $\mathrm{OH}$ & $\mathrm{OH}$ & $\mathrm{OH}$ \\
\hline
\end{tabular}<smiles>O=c1cc(-c2ccccc2)oc2cc(-c3ccccc3)oc12</smiles><smiles></smiles>

Fig. 1. The representative flavonoids in nature.

possess anti-inflammatory activity on various animal models of inflammation. Especially, some flavonoids were found to inhibit chronic inflammation of several experimental animal models. Thus, it may be valuable to continuously evaluate the anti-inflammatory activity of flavonoids, not only for establishing anti-inflammatory mechanisms, but also for developing a new class of anti-inflammatory agents.

There have been several proposed cellular action mechanisms explaining in vivo anti-inflammatory activity of flavonoids. They possess antioxidative and radical scavenging activities. They could regulate cellular activities of the inflammation-related cells: mast cells, macrophages, lymphocytes, and neutrophils. For instance, some flavonoids inhibit histamine release from mast cells and others inhibit T-cell proliferation. These properties of flavonoids have been recently summarized (2). In addition, certain flavonoids modu- 
late the enzyme activities of arachidonic acid (AA) metabolizing enzymes such as phospholipase $\mathrm{A}_{2}\left(\mathrm{PLA}_{2}\right)$, cyclooxygenase $(\mathrm{COX})$, and lipoxygenase (LOX) and the nitric oxide (NO) producing enzyme, nitric oxide synthase (NOS). An inhibition of these enzymes by flavonoids reduces the production of AA, prostaglandins (PG), leukotrienes (LT), and NO, crucial mediators of inflammation. Thus, the inhibition of these enzymes exerted by flavonoids is definitely one of the important cellular mechanisms of anti-inflammation. Furthermore, in recent years, many lines of evidence support the idea that certain flavonoids are the modulators of gene expression, especially the modulators of proinflammatory gene expression, thus leading to the attenuation of the inflammatory response. At present, it is not known to what extent these proinflammatory gene expressions contribute to the inflammatory response. However, it is evident that flavonoids show anti-inflammatory activity, at least in part, by the suppression of these proinflammatory gene expressions.

In the present review, we have summarized the findings of anti-inflammatory flavonoid research. Especially, this review is focused on two most important topics: the effect on AA metabolizing enzymes and NOS and the effect on expression of pivotal proinflammatory enzymes/cytokines. In vivo anti-inflammatory activity of flavonoids is also discussed, but the anti-inflammatory properties of tannins, anthocyanins, and silymarin are not discussed because the chemistry and biological activity of tannins and anthocyanins are quite different from the conventional flavonoids, and silymarin is not a true flavonoid, but a flavonolignan.

\section{Cellular action mechanisms}

\section{The effect on $\mathrm{PLA}_{2}$}

The inhibitory activity of several flavonoid derivatives against AA metabolizing enzymes was initially reported in 1980 (3). Thereafter, numerous investigators have studied the inhibitory effect of flavonoids on these enzymes. AA (a precursor of eicosanoids) is released mostly from membrane lipids in cells. The enzyme responsible for this release is $\mathrm{PLA}_{2}$, although some portion is attributed to the combined action of phospholipase $\mathrm{C}$ and diacylglycerol lipase. Up to date, many isoforms of $\mathrm{PLA}_{2}$ have been discovered (4). They are mainly classified into three large categories, secretory $\mathrm{PLA}_{2}\left(\mathrm{sPL}_{2}\right)$, cytosolic PLA $2\left(\mathrm{CPLA}_{2}\right)$, and calciumindependent $\mathrm{PLA}_{2}\left(\mathrm{PLA}_{2}\right)$. These $\mathrm{PLA}_{2} \mathrm{~S}$ are distributed in wide varieties of tissues and cells. In some conditions, they are coupled to COXs depending on the cells and agonists used (4). For instance, group IIA $\mathrm{sPLA}_{2}$ was found in arthritic synovial fluid, and group IV $\mathrm{cPLA}_{2}$ are coupled to COXs and 5-LOX to produce eicosanoids. On the other hand, group VI iPLA 2 is thought to serve a housekeeping role in phospholipid remodeling. Therefore, a modulation of $\mathrm{SPLA}_{2}$ and/or $\mathrm{CPLA}_{2}$ activity is important to control the inflammatory process.

The first flavonoid inhibitor of $\mathrm{PLA}_{2}$ found was quercetin, which inhibited $\mathrm{PLA}_{2}$ from human neutrophils (5). Quercetin was repeatedly found to inhibit $\mathrm{PLA}_{2}$ from several sources. It inhibited $\mathrm{PLA}_{2}$ from rabbit peritoneal neutrophils with an $\mathrm{IC}_{50}$ of $57-100$ $\mu \mathrm{M}$ (6). It was also demonstrated that quercetin selectively inhibited group II $\mathrm{sPLA}_{2}$ from Vipera russelli with less inhibition of $\mathrm{PLA}_{2}$ from porcine pancreas, $\mathrm{PLA}_{2}$-IB (7). While flavanones including flavanone, hesperetin, and naringenin showed less inhibition, flavonols such as kaempferol, quercetin, and myricetin were found to considerably inhibit snake venom $\mathrm{PLA}_{2}$, indicating an importance of the C-ring-2,3-double bond (8). The $\mathrm{IC}_{50}$ values of these flavonols were $75-$ $115 \mu \mathrm{M}$, not easily obtainable concentrations in the body even by pharmacological treatment.

On the other hand, several polyhydroxylated flavonoids were found to strongly inhibit group II human recombinant $\mathrm{PLA}_{2}$ with less inhibition against Naja naja $\mathrm{PLA}_{2}, \mathrm{PLA}_{2}$-IIB (9). The $\mathrm{IC}_{50}$ values of quercetagetin, kaempferol-3-galactoside, and scutellarein (Fig. 2) are $10-30 \mu \mathrm{M}$. Along with these flavonoids, the most potent flavonoid inhibitors of PLA $_{2}$-IIA so far being found are biflavonoids. Several biflavonoids such as ochnaflavone, amentoflavone, ginkgetin, and isoginkgetin were for the first time revealed to inhibit $\mathrm{sPLA}_{2}$-IIA from rat platelets at micromolar concentrations with some selectivity over $\mathrm{PLA}_{2}$-IB (10). The $\mathrm{IC}_{50}$ values were within $10 \mu \mathrm{M}$. Ochnaflavone inhibited sPLA $_{2}$-IIA noncompetitively. The observation that another biflavonoid, morelloflavone, possessed inhibitory activity against $\mathrm{sPLA}_{2}$ (11) supported the initial finding that certain biflavonoids were $\mathrm{PLA}_{2}$ inhibitors. The biflavonoids such as ginkgetin and bilobetin were repeatedly found to inhibit group II $\mathrm{sPLA}_{2}$ from several sources (12). When several flavonoids were examined, ginkgetin and quercetin considerably inhibited $\mathrm{cPLA}_{2}$ from guinea pig epidermis at micromolar concentrations, while amentoflavone and apigenin did not (13). $\mathrm{PLA}_{2}$ inhibition of biflavonoids was also proved in cells. Ginkgetin concentration-dependently inhibited AA release from the activated rat peritoneal macrophages (14). Recently, papyriflavonol A (prenylated flavonoid) from Broussonetia papyrifera was shown to selectively inhibit $\mathrm{PLA}_{2}$-IIA, being less active against $\mathrm{PLA}_{2}$-IB (15). In addition, it is meaningful to note that the synthetic flavone 2',4',7-trimethoxyflavone is a $\mathrm{PLA}_{2}$ inhibitor having in vivo anti-inflammatory activity 


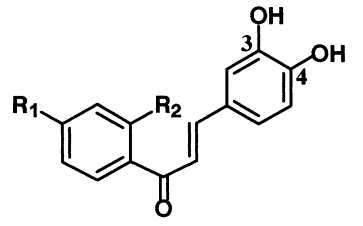

3,4-dihydroxychalcone

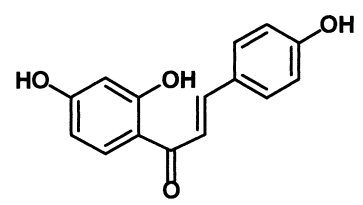

isoliquiritigenin

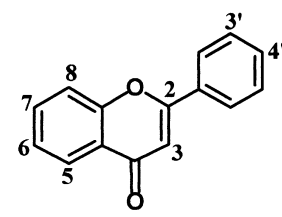

\begin{tabular}{lccccccc}
\hline & 3 & 5 & 6 & 7 & 8 & $34^{\prime}$ \\
\hline baicalein & $\mathrm{H}$ & $\mathrm{OH}$ & $\mathrm{OH}$ & $\mathrm{OH}$ & $\mathrm{H}$ & $\mathrm{H}$ & $\mathrm{H}$ \\
wogonin & $\mathrm{H}$ & $\mathrm{OH}$ & $\mathrm{H}$ & $\mathrm{OH}$ & $\mathrm{OCH}_{3}$ & $\mathrm{H}$ & $\mathrm{H}$ \\
oroxylin $\mathrm{A}$ & $\mathrm{H}$ & $\mathrm{OH}$ & $\mathrm{OCH}_{3}$ & $\mathrm{OH}$ & $\mathrm{H}$ & $\mathrm{H}$ & $\mathrm{H}$ \\
scutellarein & $\mathrm{H}$ & $\mathrm{OH}$ & $\mathrm{OH}$ & $\mathrm{OH}$ & $\mathrm{H}$ & $\mathrm{H}$ & $\mathrm{OH}$ \\
cirsiliol & $\mathrm{H}$ & $\mathrm{OH}$ & $\mathrm{OCH}_{3}$ & $\mathrm{OCH}_{3}$ & $\mathrm{H}$ & $\mathrm{OH}$ & $\mathrm{OH}$ \\
quercetagetin & $\mathrm{OH}$ & $\mathrm{OH}$ & $\mathrm{OH}$ & $\mathrm{OH}$ & $\mathrm{H}$ & $\mathrm{OH}$ & $\mathrm{OH}$
\end{tabular}

Fig. 2. Some flavonoids acting on eicosanoid and NO generating enzymes.

(H.P. Kim et al., unpublished results).

All these findings have shown that certain biflavonoids and several polyhydroxylated flavonoids are

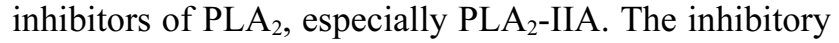
concentrations of these flavonoids are within $30 \mu \mathrm{M}$, probably achievable concentration ranges when highest doses of flavonoids are pharmacologically administered. Thus, $\mathrm{PLA}_{2}$ inhibition of some flavonoids may contribute to their anti-inflammatory property in vivo.

\section{The effect on COX and LOX}

COX that produces PGs and thromboxanes (TX) from arachidonic acid exists in two different isoforms (COX-1 and -2) and one variant (COX-3) at least (16). COX-1 is a constitutive enzyme existing in almost every cell type, affording cytoprotective PGs and blood aggregatory TXs. On the other hand, COX-2 is known as an inducible enzyme in most cases to produce large amount of PGs. COX-2 is highly expressed in the inflammation-related cell types including macrophages and mast cells, when they are stimulated with proinflammatory cytokines and/or bacterial lipopolysaccharide (LPS) (17). COX-2 that produces PGs is closely associated with inflammatory disorders of acute as well as chronic types. Actually, COX-2 selective inhibitors such as celecoxib are claimed to possess anti-inflammatory and analgesic activity with reduced side effects, previously encountered frequently by $\mathrm{COX}-1 / \mathrm{COX}-2$ nonselective inhibitors (18). However, recent several investigations have shown that highly selective COX-2 inhibitors may increase the cardiovascular risk, probably by TXs formed via the COX-1 pathway (19). In some respects, $\mathrm{COX}-1 / \mathrm{COX}-2$ nonselective inhibitors may be more favorable compared to the use of selective COX-2 inhibitors. Nonetheless, COX-2 is certainly a pivotal enzyme in inflammation, and inhibitors of COX-2 are being continuously developed to obtain safer antiinflammatory drugs.

Some flavonoids such as luteolin, 3',4'-dihyroxyflavone, galangin, and morin were for the first time found as inhibitors of COX (3). From human thrombin aggregated platelets, certain flavonoids were revealed to be COX/LOX inhibitors (20). When their structuralactivity relationships were compared, several flavone derivatives such as flavone and apigenin were found to be COX inhibitors, while some flavonol derivatives such as quercetin and myricetin were preferential LOX inhibitors. In particular, reduction of C-2,3-double bond and glycosylation reduced the inhibitory activity. Some chalcones having a 3,4-dihydroxycinnamoyl moiety (Fig. 2) were reported to inhibit COX and 12LOX from mouse epidermis, being more active on LOX (21). While some flavonoid glycosides including rutin and hypolaetin-8-glucoside rather enhanced COX activity from sheep seminal vesicle (22), certain flavonoids such as flavone, kaempferol, and quercetin were repeatedly found to be $\mathrm{COX}$ inhibitors from rat peritoneal macrophages (8). After these reports, many studies have been done to figure out the inhibitory activity of flavonoids on COX, mostly COX-1. For instance, flavonoids such as quercetin and xanthomicrol were reported to inhibit sheep platelet $\mathrm{COX}-1$, while the $\mathrm{IC}_{50}$ values of flavones including cirsiliol, hypolaetin, and diosmetin were more than $100 \mu \mathrm{M}(23)$. Furthermore, flavones and flavonols including chrysin, flavone, galangin, kaempferol, and quercetin were repeatedly revealed to inhibit $\mathrm{TXB}_{2}$ formation from mixed leukocyte suspension probably by COX-1 inhibition (24). Again, flavones were COX inhibitors and flavonols were preferential LOX inhibitors. In addition, when human platelet homogenate was used as the COX-1 and 12-LOX source, isoflavones such as tectorigenin showed weak inhibition of COX-1 (25). Although various derivatives were reported to inhibit COX-1, these conventional flavonoids mentioned above were not strong inhibitors.

Meanwhile, prenylated flavonoids including morusin and kuwanon C (Fig. 3) from mulberry tree were found to strongly inhibit COX from rat platelets (26). The following report also demonstrated that several preny- 
<smiles>CC(C)=CCc1c(-c2ccc(O)cc2O)oc2c3c(cc(O)c2c1=O)OC(C)C=C3</smiles>

morusin<smiles>CC(C)=CCc1c(-c2ccc(O)cc2O)oc2c(CC=C(C)C)c(O)cc(O)c2c1=O</smiles>

kuwanon C<smiles>C=C(C)C1Cc2c(oc3c(CC=C(C)C)c4c(cc3c2=O)C=CC(C)(C)O4)-c2c(O)cc(O)c(O)c21</smiles>

artonin B<smiles>CC(C)=CCc1c(-c2cc(O)c(O)cc2O)oc2c3c(cc(O)c2c1=O)OC(C)(C)C=C3</smiles>

artonin E<smiles>C=C(C)C(CC=C(C)C)Cc1c(O)cc(OC)c(O/C=C/c2ccc(O)cc2O)c1O</smiles>

kuraridin<smiles>CC(C)=CCc1cc(-c2oc3cc(O)c(CC=C(C)C)c(O)c3c(=O)c2O)cc(O)c1O</smiles><smiles>C=C(C)C(CC=C(C)C)Cc1c(O)cc(OC)c2c1O[C@H](c1ccc(O)cc1O)CC2=O</smiles>

kurarinone<smiles>C=C(C)C(CC=C(C)C)Cc1c(O)cc(O)c2c1O[C@H](c1ccc(O)cc1O)CC2=O</smiles>

sophoraflavanone G

Fig. 3. Some anti-inflammatory prenylated flavonoids.

lated flavonoids including kuwanons and sanggenon D were COX inhibitors (27). Several prenylated flavonoids such as cycloheterophyllin, broussochalcone A, broussoaurone $\mathrm{A}$, and broussoflavonol $\mathrm{F}$ inhibited platelet aggregation and inhibited COX from ram seminal vesicle $\left(\mathrm{IC}_{50}\right.$ of $17.5-26.1 \mu \mathrm{g} / \mathrm{ml}$ ) (28). Recently, some other prenylated flavonoids including kuraridin, kurarinone, and sophoraflavanone $G$ were found to possess potent COX-1 inhibitory activity from bovine platelet homogenate at micromolar concentrations $\left(\mathrm{IC}_{50}=0.1-1 \mu \mathrm{M}\right)$, being comparable to indomethacin $\left(\mathrm{IC}_{50}=0.9 \mu \mathrm{M}\right)(29)$. These potent COX-1 inhibitory flavonoids have the C-8 lavandulyl moiety as their common structure (Fig. 3). It is noteworthy that amentoflavone (biflavone) potently inhibited COX-1 from guinea-pig epidermis with an $\mathrm{IC}_{50}$ of $3 \mu \mathrm{M}$ compared to the $\mathrm{IC}_{50}$ of $1 \mu \mathrm{M}$ of indomethacin, while ginkgetin did not significantly inhibit COX-1 and LOX (30). All these findings clearly demonstrated that some flavonoids are more or less COX-1 inhibitors. They include flavones/flavonols such as flavone, apigenin, luteolin, galangin, kaempferol, and quercetin; prenylated flavonoids such as morusin, broussochalcone A, and kuraridin; and the biflavonoid amentoflavone. Especially, kuraridin, kurarinone, and sophoraflavanone G are potent COX-1 inhibitors.

On the other hand, flavonoids inhibiting COX-2 have been rarely reported. Several flavan-3-ols such as catechin and 4'-Me-gallocatechin were found to weakly inhibit COX-2 at high concentrations $(>100 \mu \mathrm{M})$, being more active on COX-1 (31). When various flavonoids were examined in order to find reasonably selective COX-2 inhibitors, quercetin and some prenylated flavonoids moderately inhibited COX-2, but their selectivity over COX-1 was generally low (29). Morusin, kuwanon $\mathrm{C}$, sanggenon $\mathrm{B}$, sanggenon $\mathrm{D}$, and kazinol $\mathrm{B}$ showed moderate inhibitory activity on COX-2. Their $\mathrm{IC}_{50}$ values against COX-2 homogenate from LPStreated RAW 264.7 cells were 100, >100, >100, 73, and $>100 \mu \mathrm{M}$, respectively. These COX-2 inhibitory prenylated flavonoids, except kazinol $\mathrm{B}$, have a common chemical structure, the $\mathrm{C}-3$ isoprenyl residue. Despite of low selectivity on $\mathrm{COX}-2 / \mathrm{COX}-1$, these prenylated flavonoids may have a potential for new anti-inflam- 
matory agents since COX-1/COX-2 mixed inhibitors are preferable in some cases as mentioned above. The prenylated flavonoids including lonchocarpol A from Macaranga conifera were also demonstrated to inhibit COX-1/COX-2 (32). Lonchocarpol A and tomentosanol D showed some COX-2 inhibitory selectivity over COX-1. Two dihydrochalcones were revealed to be weak inhibitors of $\mathrm{COX}-1 / \mathrm{COX}-2$ with no selectivity on COX-1/COX-2 (33). Several catechins and gallated catechins showed $\mathrm{COX}-1 / \mathrm{COX}-2$ inhibition at $80 \mu \mathrm{M}$ (approximately $20-70 \%$ inhibition). The galloyl moiety seems to be important for inhibition, but significant selective inhibition on COX-2 was not observed (34). Up to the present, the efforts to find highly selective COX-2 inhibitory flavonoid have been unsuccessful. The only COX-2 inhibitory flavonoid with reasonable preference over COX-1 reported so far is wogonin (described in a later separate section). Collectively, it is revealed that some flavonoids are COX-1/COX-2 inhibitors, and in vivo anti-inflammatory activity may be contributed by these inhibitory properties to reduce prostanoid production.

LOXs are the enzymes responsible for generating hydroxy acids and LTs from AA. 5-, 8-, 12-, and 15LOXs have been found from different cells/tissues. While 15-LOX synthesizes anti-inflammatory 15hydroxyeicosatetraenoic acid (15-HETE), 5- and 12LOXs are involved in provoking inflammatory/allergic disorders. 5-LOX produces 5-HETE and LTs. 5-HETE, $\mathrm{LTA}_{4}$, and $\mathrm{LTB}_{4}$ are potent chemoattractants. $\mathrm{LTC}_{4}$, $\mathrm{LTD}_{4}$, and $\mathrm{LTE}_{4}$, also known as slow-reacting substance of anaphylaxis (SRS-A), contract respiratory smooth muscle, producing the syndrome of asthma. 12-LOX synthesizes 12-HETE, which aggregates platelets and induces the inflammatory response. Therefore, the effect of flavonoids on 5- and 12-LOXs has been extensively studied to elucidate the anti-inflammatory property. A review summarizing the previous findings of LOX inhibition to the early $1990 \mathrm{~s}$ is available (2).

Flavonols including kaempferol, quercetin, morin, and myricetin were found to be 5-LOX inhibitors that were less active against 12-LOX, but they were stronger inhibitors than flavones $(8,24)$. Exceptions were the flavone derivatives including cirsiliol and its analogues. They strongly inhibited 5-LOX, being far less active on 12-LOX (35). Based on cirsiliol molecule, C-6 and C-8 alkyloxyflavones having a B-ring 3',4'-dihydroxyl group were synthesized and some of them were found to be potent 5-LOX inhibitors ( $\mathrm{IC}_{50}$ in the $10 \mu \mathrm{M}$ range) (36). Against 12-LOX, flavonols such as quercetin, quercetagetin-7-O-glucoside, and hibifolin were found to be potent inhibitors. Flavones including 5,6,7trihydroxyflavone (baicalein), hypolaetin, and siderito- flavone were also strong inhibitors of 12-LOX. However, flavanones such as naringenin were not inhibitory against 5- and 12-LOXs, indicating the importance of the C-2,3-double bond. It is significant to note that flavonols such as quercetin, fisetin, and kaempferol strongly inhibited 12-LOX from mouse epidermis (37), and quercetin also inhibited 12-/15-LOX from guinea pig epidermal homogenate (30).

In particular, some prenylated flavonoids such as artonins (Fig. 3) are the most potent inhibitors of 5-LOX with less inhibition on 12-LOX (38). The $\mathrm{IC}_{50}$ values of artonins against 5-LOX purified from porcine leukocytes were $0.36-4.3 \mu \mathrm{M}$. Recently, 19 prenylated flavonoids were examined on 5-LOX from bovine PMNs and 12-LOX from bovine platelets (29). Sophoraflavanone $\mathrm{G}$ and kenusanone A potently inhibited 5-LOX. The $\mathrm{IC}_{50}$ values were $0.09-0.25$ and $0.5-0.9 \mu \mathrm{M}$, respectively, compared to the $\mathrm{IC}_{50}$ of $0.6-0.9 \mu \mathrm{M}$ by the known LOX inhibitor nordihydroguaiaretic acid (NDGA). Kuraridin, papyriflavonol A, sanggenon $\mathrm{B}$, and sanggenon $\mathrm{D}$ showed moderate inhibition against 5-LOX. Against 12-LOX, however, most prenylated flavonoids tested were not so active. Only sophoraflavanone $\mathrm{G}$, kuwanon $\mathrm{C}$, and papyriflavonol $\mathrm{A}$ showed moderate inhibition. Their $\mathrm{IC}_{50}$ values were 20 , 19 , and $29 \mu \mathrm{M}$, compared to the $2.6 \mu \mathrm{M}$ of NDGA. As described above, certain flavonoids are 5-/12-LOX inhibitors. Especially, artonins and some other prenylated flavonoids are the most potent 5-LOX inhibitors. Although it is difficult to establish structural-activity relationships due to their varieties of chemical structures, these inhibitory activities against 5- and 12-LOXs could explain, at least in part, the anti-inflammatory /antiallergic activities of flavonoids.

\section{The effect on NOS}

$\mathrm{NO}$ is one of the cellular mediators of physiological and pathological process $(39,40)$. NO is biochemically synthesized from L-arginine by NOS. Three different isoforms of NOS have been discovered: endothelial NOS (eNOS), neuronal NOS (nNOS), and inducible NOS (iNOS). The former two are constitutively expressed in the body, whereas the latter type is an inducible enzyme highly expressed by inflammatory stimuli in certain cells such as macrophages. It is meaningful to evaluate the effects of flavonoids on NOS (effect on NO production), since $\mathrm{NO}$ is one of the inflammatory mediators. The compounds to reduce NO production by iNOS without affecting eNOS or nNOS may be desirable for anti-inflammatory agents.

When quercetin and several other flavonoids were examined on the enzyme activity of eNOS, nNOS, and iNOS, only quercetin weakly inhibited eNOS activity at 
high concentrations $\left(\mathrm{IC}_{50}=220 \mu \mathrm{M}\right)(41)$. No significant inhibition against nNOS and iNOS was observed. Other flavonoids including rutin, hesperidin, catechin, and tricin inhibited none of the three forms of NOS. This study has shown that quercetin is able to inhibit eNOS. However, the inhibitory activity found is not likely exhibited in vivo because the concentrations of quercetin inhibiting eNOS are not physiologically or pharmacologically obtainable. On the other hand, it was demonstrated that quercetin- or catechin-rich diets enhanced NO production and NOS activity of aortic rings of rats, suggesting some evidence of flavonoid activation of eNOS activity (42). In the near future, many more flavonoids should be examined on eNOS and nNOS in order to establish the real effect.

The effect of flavonoids on iNOS has been intensively studied since NO production by iNOS is closely associated with inflammatory conditions. Macrophages respond to an inflammatory signal like LPS and interleukin-1 $\beta$ (IL-1 $\beta$ ), and iNOS is induced. Using LPS /cytokine-treated macrophages or macrophage-like cell lines, varieties of flavonoids including apigenin, luteolin, and quercetin were found to inhibit NO production. However, the mechanism studies have shown that flavonoids did not significantly inhibit iNOS. They were revealed to down-regulate iNOS induction, reducing NO production (discussed in the following section). The only exception found was echinoisosophoranone, significantly inhibiting iNOS at reasonable concentrations (43). While there is some possibility to inhibit eNOS or nNOS, flavonoids are not efficient iNOS inhibitors.

\section{Effects on the expression of iNOS and COX-2}

While a small amount of NO synthesized by eNOS and nNOS is essential for maintaining normal body function (homeostasis), a significantly increased amount of NO synthesized by iNOS participates in provoking inflammatory process and acts synergistically with other inflammatory mediators (40). Therefore, inhibition of iNOS activity or down-regulation of iNOS expression may be beneficial to reduce the inflammatory response.

As described above, iNOS inhibition is not a general property of flavonoids, but they inhibit NO production. Flavone and several other amino-substituted flavones were reported to inhibit NO production (44). Genistein was proved to inhibit LPS-induced NO production in macrophages (45). Several flavonoid derivatives including apigenin, quercetin, and morin also inhibited NO production from LPS/interferon (IFN)- $\gamma$-activated C6astrocytes (46). However, in these reports, no further cellular mechanism was elucidated. Thus, for the purpose of finding cellular action mechanisms and optimum chemical structures, structural-activity relationships were elucidated using structurally diverse naturallyoccurring flavonoids in LPS-treated RAW 264.7 cells, a mouse macrophage-like cell line (47). From the results, it was found that catechins and flavanones were not active up to $100 \mu \mathrm{M}$. Some flavones/flavonols/isoflavones, mainly flavones, considerably inhibited NO production. On the other hand, flavonoid glycosides such as vitexin regardless of chemical structures of aglycones did not significantly inhibit NO production up to $100 \mu \mathrm{M}$. In general, flavones showed stronger inhibition of NO production than flavonols. Apigenin, wogonin, and luteolin $\left(\mathrm{IC}_{50}=10-20 \mu \mathrm{M}\right)$ were the most active inhibitors among natural flavonoids tested. These results strongly suggest that the C-2,3-double bond is crucial for inhibiting NO production and hydroxyl substitutions on A- and B-ring influence the inhibitory activity. A-ring 5-/7- and B-ring 3-/4hydroxylation(s) gave favorable results while C-3 hydroxylation (flavonol) did not. It was also demonstrated that the active flavonoids did not significantly inhibit iNOS activity. Instead, they strongly suppressed iNOS expression. These findings were well matched with the study that apigenin, genistein, and kaempferol inhibited NO production by iNOS down-regulation (48). Following these investigations, many researchers reported the similar property of various flavonoids. The iNOS down-regulating flavonoids found were summarized in Table 1. They include flavones such as apigenin and oroxylin A, flavonols such as kaempferol and quercetin, biflavonoids such as bilobetin and ginkgetin, and some prenylated flavonoid such as sanggenons and kuwanon $\mathrm{C}$. It is worth mentioning that some parts of the inhibitory activity of NO production from LPS-induced RAW 264.7 cells by several prenylated flavonoids were associated with their cytotoxic property since most prenylated flavonoids tested showed cytotoxicity to RAW cells at higher than $50 \mu \mathrm{M}$ (43). Taken together, all these investigations strongly suggest that some flavonoids are natural inhibitors of iNOS induction, but not iNOS inhibitors.

Another important evidence was published that apigenin, genistein, and kaempferol strongly inhibited COX-2 induction by inhibiting nuclear transcription factor- $\kappa \mathrm{B}(\mathrm{NF}-\kappa \mathrm{B})$ activation via inhibitor $-\kappa \mathrm{B}(\mathrm{I} \kappa \mathrm{B})$ kinase inhibition (48). Most active one among the tested compounds was apigenin. However, the derivatives including apigenin, genistein, and kaempferol did not significantly inhibit COX-2, while epigallocatechin-3gallate and quercetin slightly inhibited it. Isoflavones, tectorigenin, and tectoridin from Belamcanda Radix were also proved to inhibit $\mathrm{PGE}_{2}$ production and COX-2 expression from LPS-treated rat peritoneal macrophages 
(58). Oroxylin A (flavone) from Scutellaria radix possessed the similar property of COX-2 and iNOS suppression through inhibition of NF- $\kappa \mathrm{B}$ activation (51). In another experiment using the gene-reporter assay to express COX-2, some flavones and flavonols were proved to be active suppressors, but epigallocatechin-3gallate, catechin, and myricetin were not (59).

Table 2 summarized the findings of flavonoids having COX-2 down-regulating capacity. Various types of flavonoids were revealed as down-regulators of COX-2 induction. As in the case of iNOS down-regulation, certain flavone derivatives such as apigenin, wogonin, and luteolin showed higher suppressive activity of
COX-2 expression compared to the flavonol derivatives including quercetin. C-2,3-double bond and patterns of hydroxylation/methoxylation on A- and B-ring seem to be important. Biflavonoids such as amentoflavone, bilobetin and ginkgetin were appeared to inhibit COX-2 induction. Nonetheless, the structural-activity relationships of flavonoids for COX-2 down-regulation are not clear. In contrast to the effect on iNOS, the effect of flavonoids on COX-2 is not simple, because some flavonoids possess COX-2 inhibitory activity as well as COX-2 down-regulation capacity. Moreover, certain flavonoids are $\mathrm{PLA}_{2}$ inhibitors as described in earlier section. So it is not feasible to establish structural-acti-

Table 1. Down-regulation of iNOS expression in various cells by naturally-occurring flavonoids ${ }^{\mathrm{a}}$

\begin{tabular}{|c|c|c|c|}
\hline Compounds & Target cells & iNOS induced by & Reference \\
\hline epigallocatechin gallate & mouse peritoneal cell & $\mathrm{LPS} / \mathrm{IFN}-\gamma$ & 49 \\
\hline \multicolumn{4}{|c|}{ wogonin, flavone, apigenin, chrysin, luteolin, kaempferol, quercetin, myricetin, genistein, tectorigenin } \\
\hline & RAW 264.7 & LPS & 47 \\
\hline apigenin, genistein, kaempferol & RAW 264.7 & LPS & 48 \\
\hline bilobetin, ginkgetin & RAW 264.7 & LPS & 11 \\
\hline \multicolumn{4}{|c|}{ bilobetin, ginkgetin, isoginkgetin, ochnaflavone, morusin, kuwanon C, kazinol B, } \\
\hline sanggenon $\mathrm{B}$ and $\mathrm{D}$, echinoisoflavanone & RAW 264.7 & LPS & 43 \\
\hline nobiletin & RAW 264.7 & LPS $/ \mathrm{IFN}-\gamma$ & 50 \\
\hline oroxylin A & RAW 264.7 & LPS & 51 \\
\hline wogonin & RAW 264.7 & LPS & 52 \\
\hline apigenin, quercetin, galangin & J774A.1 & LPS & 53 \\
\hline wogonin & C6 rat glial cell & LPS/IFN- $\gamma /$ TNF- $\alpha$ & 54 \\
\hline quercetin, wogonin, rutin & RAW 264.7 & LPS & 55 \\
\hline epigallocatechin-3-gallate & human chondrocyte & IL- $1 \beta$ & 56 \\
\hline isoliquiritigenin & RAW 264.7 & LPS & 57 \\
\hline
\end{tabular}

${ }^{\text {a }}$ Several reports demonstrating the similar results are not represented here.

Table 2. Down-regulation of COX-2 expression in various cells by naturally-occurring flavonoids ${ }^{\mathrm{a}}$

\begin{tabular}{lllc}
\hline Compounds & Target cells & COX-2 induced by & Reference \\
\hline apigenin, genistein, kaempferol, quercetin, myricetin & RAW 264.7 & LPS & 48 \\
tectorigenin, tectoridin & rat peritoneal macrophage & LPS & 58 \\
bilobetin, ginkgetin & RAW 264.7 & LPS & 11 \\
nobiletin & RAW 264.7 & LPS/IFN- $\gamma$ & 50 \\
quercetin, rhamnetin, genistein, eriodictyol, luteolin, kaempferol, fisetin, phloretin & & 59 \\
& human colon cancer DLD-1 (gene reporter assay) & 59 \\
wogonin & RAW 264.7 & LPS & 60 \\
oroxylin A & RAW 264.7 & 51 \\
flavone & human colon cancer HT-29 & 61 \\
apigenin, quercetin, galangin & J774A.1 & LPS & 53 \\
wogonin & RAW 264.7 & LPS \\
quercetin, wogonin & RAW 264.7 & LPS \\
amentoflavone & A549 & TNF- $\alpha$ & 55 \\
nobiletin & human synovial fibroblast & IL-1 $\alpha$ & 62 \\
isoliquiritigenin & RAW 264.7 & LPS \\
\hline
\end{tabular}

${ }^{a}$ Several reports demonstrating the similar results are not represented here. 
vity relationships simply by measuring the inhibitory potency of prostanoid production from COX-2-induced cells like LPS-treated RAW 264.7 cells. For a clear comparison of COX-2 down-regulating potential, Western/Northern/RT-PCR analysis should be carried out in each flavonoid derivative. All these findings have shown that many flavonoids, mainly flavones, possess the down-regulating capacity of iNOS and/or COX-2 induction, and flavonoid lists in this category are expanding. These cellular actions of flavonoids certainly contribute to their anti-inflammatory activity in vivo.

\section{The effect on the production of other proinflammatory molecules}

In addition to COX-2/iNOS, several cytokines are deeply associated with inflammatory diseases. In particular, tumor necrosis factor- $\alpha$ (TNF- $\alpha$ ) and IL- $1 \beta$ are prominent contributors to chronic inflammatory disorders including RA (64). In recent years, TNF- $\alpha$ and IL-1 $\beta$ receptor antagonists have been clinically successful to improve the symptoms of RA patients. SAIDs such as prednisolone and dexamethasone are known to reduce the production of these cytokines.

Genistein was reported to inhibit IL- $1 \beta$, IL-6, and TNF- $\alpha$ production in LPS-induced human blood monocytes (65). Amoradicin, genistein, and silybin were proved to inhibit TNF- $\alpha$ production from LPS-treated RAW 264.7 cells (66). Baicalin inhibited the induction of IL- $1 \beta$, IL- 6 , TNF- $\alpha$, IFN- $\gamma$, monocyte chemotactic protein-1, macrophage inflammatory protein (MIP)-1 $\alpha$, and MIP- $\beta$ at protein as well as at RNA levels from human blood monocytes treated with staphylococcal enterotoxin (67). In human dermal fibroblasts induced by IL-4 plus TNF- $\alpha$, baicalein $>$ oroxylin A > baicalin $>$ skullcapflavone II inhibited eotaxin production (68).
Some flavonoids such as fisetin were recently revealed to inhibit $\mathrm{T}_{\mathrm{H}}$ 2-type cytokine production including IL-4, IL-13, and IL-5 by activated human basophils (69). Table 3 summarizes the findings of flavonoids inhibiting the production of proinflammatory cytokines. These results suggest the favorable effect of flavonoids on improving clinical symptoms of inflammatory and allergic diseases.

\section{Mechanisms of modulating proinflammatory gene expression}

The cellular action mechanisms of flavonoids for modulating gene expression have been actively studied. The most prominent points of cellular regulation affected by flavonoids are the various protein kinases involved in signal transduction including protein kinase $\mathrm{C}$ (PKC) and mitogen activated protein kinase (MAPK). Through the inhibition of these enzymes, DNA-binding capacity of transcription factors such as $\mathrm{NF}-\kappa \mathrm{B}$ or activator protein-1 (AP-1) is regulated. Thereby, the expression rate of the target gene is controlled.

Flavonoids were reported to inhibit the enzyme activities of various signal transduction protein kinases. The best example is PKC inhibition (77) and protein tyrosine kinase inhibition (78) by various flavonoid derivatives. MAPKs are also key elements in signal transduction. Especially, in macrophages, LPS activates three kinds of MAPKs, extracellular signal related kinase (ERK), p38 MAPK, and Jun N-terminal kinase/stress activated protein kinase (JNK/SAPK) (79). Quercetin inhibited iNOS expression by inhibiting p38 MAPK (80) and inhibited TNF- $\alpha$-induction from LPS-induced RAW cells by inhibiting JNK/SAPK, leading to the inhibition of AP-1-DNA binding (72). In a separate pathway, quercetin inhibited ERK $1 / 2$ and $\mathrm{p} 38$ MAPK to regulate

Table 3. Inhibition of proinflammatory cytokine production in various cells by naturally-occurring flavonoids ${ }^{\mathrm{a}}$

\begin{tabular}{|c|c|c|c|c|}
\hline Compounds & Target cells & Agonist & Target genes inhibited & Reference \\
\hline genistein & human PBMC & LPS & IL- $1 \beta$, IL- 6 , TNF- $\alpha$ & 65 \\
\hline apigenin & HUVEC & TNF- $\alpha$ & IL-6, IL-8 & 70 \\
\hline wogonin, baicalein, baicalin & human gingival fibroblast & LPS & IL- $1 \beta$ & 71 \\
\hline amoradicin, genistein & RAW 264.7 & LPS & TNF- $\alpha$ & 66 \\
\hline quercetin & RAW 264.7 & LPS & TNF- $\alpha$ & 72 \\
\hline baicalin & human PBMC & SE & $\begin{array}{l}\text { IL-1 } \beta \text {, IL-6, IFN- } \gamma, \\
\text { MCP-1, MIP-1, TNF- } \alpha\end{array}$ & 67 \\
\hline wogonin & RAW 264.7 & LPS & TNF- $\alpha$ & 73 \\
\hline luteolin & RAW 264.7 & LPS & TNF- $\alpha$ & 74 \\
\hline quercetin & RAW 264.7 & LPS & IL- $1 \beta$, IL- 6 , TNF- $\alpha$ & 75 \\
\hline \multirow[t]{2}{*}{ wogonin, baicalein } & \multicolumn{4}{|c|}{ human retinal pigment epithelial cell (ARPE-19) } \\
\hline & & $\mathrm{IL}-1 \beta$ & IL-6, IL-8 & 76 \\
\hline
\end{tabular}

a Several reports demonstrating the similar results with others are not represented here. Pheripheral blood mononuclear cell (PBMC), human umbilical vein endothelial cell (HUVEC), staphylococcal enterotoxin (SE). 
the post-transcriptional level of TNF- $\alpha$. Recently, it has been also shown that quercetin inhibited NF- $\kappa$ B activation by ERK and p38 kinase inhibition (75). Wogonin inhibited monocyte chemotactic protein-1 gene expression of 12-O-tetradecanoylphorbol 13-acetate (TPA)induced human endothelial cells by AP-1 repression through ERK 1/2 and JNK inhibition (81). In another study, wogonin inhibited NF- $\kappa$ B activation from C6glial cells (54) and from human retinal pigment epithelial cells (76). Some other flavonoids including genistein (65), apigenin, kaempferol (48), oroxylin A (51), epigallocatechin 3-gallate (56), and amentoflavone (62) inhibited NF- $\kappa$ B activation. In Rat-1 fibroblasts, luteolin inhibited LPS-stimulated interaction between the p65 subunit of NF- $\kappa \mathrm{B}$ and the transcriptional coactivator, cyclic AMP response element-binding protein (CREB) (82); and in RAW 264.7 cells, the same compound inhibited several MAP kinases such as ERK, p38 MAPK, and casein kinase 2 (CK2) (74).

All of the above results have clearly shown that flavonoids inhibited the expression of various inflammation-related proteins/enzymes, at least partly, by suppressing activation of transcription factors such as $\mathrm{NF}-\kappa \mathrm{B}$ and AP-1. These suppressions might be mediated via inhibition of several protein kinases involved in the signal transduction pathway. There is also some evidence demonstrating that flavonoids might inhibit iNOS and COX-2 expression by activating peroxisome proliferator-activated receptor- $\gamma(62,83)$ and might act as inhibitors of proteasome activity (84).

\section{In vivo effect on the expression of proinflammatory molecules}

Although numerous studies clearly demonstrated that certain flavonoids are regulators of proinflammatory gene expression in various cells, there have been only a few investigations to prove the same effect of flavonoids in vivo.

Flavonoids such as quercetin and rutin when administered intraperitoneally were found to suppress lethal endotoxic shock induced by LPS or LPS plus D-galactosamine in mice (85), and rutin reduced TNF- $\alpha$ production. Another example is wogonin. This compound was for the first time proved to inhibit COX-2 induction when topically applied on TPA-treated mouse skin (86). Wogonin also inhibited lethal shock in mice induced by LPS and D-galactosamine, when intraperitoneally administered. It inhibited TNF- $\alpha$ production (73). The similar inhibition of COX-2 induction on TPAtreated mouse skin was observed when ginkgetin (biflavonoid) was topically applied (87). This compound also inhibited edematic response dose-dependently. In LPS-treated mice, luteolin intraperitoneally admin- istered increased the survival rate and inhibited the expression of TNF- $\alpha$ and ICAM-1 (88). Orally administered luteolin also showed inhibition of TNF- $\alpha$ production in LPS-treated mice (89). Important evidence was obtained in studies showing that locally injected quercetin inhibited release of TNF- $\alpha$, RANTES, MIP-2 from carrageenan-induced air-pouch exudates and also inhibited COX-2 expression from exudates cells in rats with concomitant reduction of $\mathrm{PGE}_{2}$ concentration (90). Since RANTES, a CC-chemokine, is a powerful chemoattractant for basophils, eosinophils, and T-lymphocytes, quercetin might prevent the further recruitment of these inflammatory cells to the site and reduce the inflammatory response.

All these studies have proved that several flavonoids including wogonin, luteolin, and quercetin really inhibit the expression of proinflammatory molecules in experimental animals, and these findings suggest that the modulation of proinflammatory gene expression is certainly one of major action mechanism(s) of flavonoids explaining their anti-inflammatory activity. Unlike NSAIDs, these modulating activities are unique and new to anti-inflammatory flavonoids. However, it is only the beginning. To clearly establish the in vivo effect, varieties of flavonoids should be further examined in various animal models of inflammation.

\section{Wogonin as an anti-inflammatory agent}

Wogonin (5,7-dihydroxy-8-methoxyflavone) is a major constituent found in the Scutellaria species, especially in Scutellaria baicalensis. This plant has been used for inflammatory diseases in Chinese medicine orally or topically. When administered orally, wogonin and its analogues, baicalein and baicalin, were found to show anti-inflammatory activity in several animal models of inflammation (91). Especially, wogonin $(100 \mathrm{mg} / \mathrm{kg}$ per day) strongly inhibited arthritic inflammation in rats. However, no clear cellular mechanism was demonstrated, until the down-regulating capacity of proinflammatory molecules was discovered.

Wogonin was found to inhibit NO production by iNOS and $\mathrm{PGE}_{2}$ production by COX-2 from LPSinduced macrophages $(47,52,54,55,92)$. The $\mathrm{IC}_{50}$ values of wogonin were 31 and $0.3 \mu \mathrm{M}$ for $\mathrm{NO}$ and $\mathrm{PGE}_{2}$ production, respectively, from LPS-induced RAW cells (52). Wogonin did not inhibit iNOS, but strongly inhibited iNOS induction. Moreover, it inhibited COX-2 expression as well as COX-2 activity $(52,60)$. On the other hand, the same compound did not significantly inhibit COX-1 and 12-LOX from human platelet homogenate up to $100 \mu \mathrm{M}$ (25). The COX-2 selective action of wogonin was also supported by the finding 
that this compound inhibited $\mathrm{PGE}_{2}$ production, but not $\mathrm{LTB}_{4}$ production from IL- $1 \beta$-induced gingival fibroblasts (71). Therefore, wogonin may be the first flavonoid inhibitor of COX-2 that does not affect COX-1 and LOX. A recent study also revealed that wogonin inhibited IL- 6 and IL- 8 production from IL- $1 \beta$-treated human retinal pigment epithelial cell line (76). It was also observed that wogonin prevented TNF- $\alpha$ and IL- $1 \beta$ induction from LPS-treated RAW 264.7 cells (H.P. Kim et al., unpublished results). Although the downregulating property of wogonin was similar with those of SAID, the same flavonoid did not use glucocorticoid receptors for expressing its activity (52). The downregulation of gene expression is not a general property of wogonin since this compound enhanced TNF- $\alpha$ and iNOS mRNA expressions in normal RAW 264.7 cells at micromolar concentrations (93). These results indicate that wogonin (maybe some other flavonoids) acts differentially depending on the cell status, normal or activated.

In vivo regulation of the expression of proinflammatory molecules by wogonin was also demonstrated. Wogonin topically applied was for the first time proved to inhibit COX-2 induction on mouse skin induced by multiple treatment of TPA (86). This compound also inhibited TNF- $\alpha$ production in LPS/D-galactosaminetreated mice when administered intraperitoneally at $350 \mu \mathrm{g} /$ mouse (73). Recently, intravenously injected wogonin was proved to inhibit in vivo production of NO by LPS treatment (55), but the same compound did not reduce $\mathrm{PGE}_{2}$ production and $\mathrm{COX}-2$ induction. One possible explanation was proposed that in vivo and in vitro LPS-induced $\mathrm{PGE}_{2}$ production might be carried out through distinct pathways. However, there may be another explanation for this phenomenon. Wogonin clearly inhibited COX-2 induction in vitro from several cell types and in vivo by topical treatment on TPAtreated mouse skin. Wogonin in the systemic circulation may be converted rapidly to metabolites that could affect iNOS induction, but not COX-2. The pharmacokinetic and metabolism studies need to be done to prove this possibility. In transient global ischemia of experimental brain injury in rats, wogonin reduced induction of iNOS and TNF- $\alpha$ in hippocampus (94).

When topically applied on mouse skin $(50-200 \mu \mathrm{g}$ /ear per day), wogonin inhibited proinflammatory gene expression in several animal models of skin inflammation $(95,96)$. Each animal model expressed some different array of proinflammatory molecules in a skin lesion, as measured by RT-PCR analysis. Mouse skin with acute inflammation stimulated by AA treatment (AA-induced ear edema) provoked the induction of COX-2 and IL- $1 \beta$ mRNAs among 6 inducible genes examined, while the constitutive genes including COX1 and fibronectin were constantly expressed. The proinflammatory genes including COX-2, IL- $1 \beta$, TNF- $\alpha$, and ICAM-1 were expressed in a subchronic inflammation model induced by multiple treatment of TPA for three consecutive days. In a model of delayed hypersensitivity (picryl chloride-induced dermatitis), $\mathrm{COX}-2, \mathrm{IL}-1 \beta$, ICAM-1, and IFN- $\gamma$ were strongly expressed, while iNOS mRNA was weakly observed. In these models of skin inflammation, wogonin down-regulated the expression of the inducible genes with different sensitivities, along with the inhibition of the edematic response. Wogonin strongly inhibited COX-2 and TNF- $\alpha$ expression, with less inhibition of IL- $1 \beta$ and ICAM- 1 expression. In contrast, topically applied wogonin on the intact mouse skin enhanced COX-1 and fibronectin mRNA expression. The reference SAID, prednisolone, showed similar inhibition of the induction of these proinflammatory molecules. These results revealed some important properties of wogonin. Wogonin was found to really act as a transcription regulator in vivo. And wogonin showed some differential actions depending on the target genes and the status of tissues. Most of all, these findings suggest the potential use of wogonin for several skin disorders by topical application. The topical route has advantages of maintaining a high concentration in a local area and avoiding breakdown to inactive metabolites in the systemic circulation. Therefore, these studies open the possibility of pharmacological treatment with topical flavonoids on chronic skin diseases such as AD. Topically applied wogonin on the skin of AD patients may inhibit the induction of proinflammatory molecules and reduce prostanoid and $\mathrm{NO}$ concentrations, leading to the improvement of the symptoms. A clinical trial is needed.

\section{In vivo anti-inflammatory activity of flavonoids}

A previous report estimated daily total flavonoid intake of approximately $1 \mathrm{~g}$ /person (97). Another study gave the value of daily flavonoid intake as $23 \mathrm{mg}$ /person, when the contents of major aglycones were measured (98). In Northeast Asia including Korea, Japan, and China, the actual value would be higher since oral onion and soy product consumption are significantly higher in most people. Whether flavonoids from daily food intake really affect an inflammatory response in the body is not clearly established. No clinical data showing the relation of flavonoid intake and incidence (severity) of inflammatory disorders such as RA and AD was available, although several studies demonstrated some inverse correlation of flavonoid intake and incident rate of cardiovascular failure (99). 
On the other hand, the effect by pharmacological treatment of flavonoids is quite different. From ancient times, varieties of flavonoids have been used clinically as major constituents in Chinese medicine. As a form of plant extracts, they could improve the symptoms of acute inflammatory as well as chronic inflammatory disorders including $\mathrm{RA}, \mathrm{AD}$, and some allergic disorders. Besides, there have been numerous reports describing the anti-inflammatory flavonoids as active principles of the medicinal plants. These studies used different animal models and different routes of administration, so that it is not feasible to establish in vivo structural-activity relationships with the data. Nonetheless, as described above, it seems to be true that the pharmacological treatment with certain flavonoids may affect, at least in part, some inflammatory responses in clinical situations. Review papers summarizing the previous findings up to 1980 's are available $(100,101)$.

Various flavonoid derivatives inhibited TPA-induced mouse ear edema when applied topically (102). The active flavonoids were mainly flavones/flavonols (having C-2,3-double bond), especially flavones such as apigenin and luteolin, and flavonols such as kaempferol and quercetin. In flavones and flavonols of the same type, flavonols showed greater inhibition than flavones. Hydroxylations at 5, 7, and 4' enhanced anti-inflammatory activity. Following this investigation, our group elucidated in vivo anti-inflammatory activity of various flavonoids isolated from the medicinal plants in order to find structural-activity relationships and in vivo action mechanisms $(103,104)$. When croton oil-induced and AA-induced mouse ear edema bioassays were used and flavonoids were administered orally or topically, the following structural-activity relationships were found. Flavan-3-ols and flavanones such as naringenin were not active in croton oil-induced edema. The certain flavones/flavonols such as apigenin, quercetin, and morin showed significant, but weak anti-inflammatory activity $(12-28 \%$ inhibition) by oral $(100 \mathrm{mg} / \mathrm{kg})$ and topical $(2 \mathrm{mg} / \mathrm{ear})$ routes. The isoflavones including biochanin A possessed similar anti-inflammatory activity with apigenin and quercetin. The various glycosides derivatives of apigenin, kaempferol, and quercetin showed comparable activities with their aglycones by oral administration. In general, flavonoid glycosides showed a higher activity against AA-induced ear edema than croton oil-induced edema by oral administration. However, no clear structural-activity relationship was found depending on the positions or types of sugar substitution. It may be thought that the differences in the activities of flavonoid glycosides tested might be due to their differences in bioavailability and/or metabolism because the aglycones are the same in the same types of flavonoids. While most flavonols showed relatively weak anti-inflammatory activity by oral administration, most flavones/flavonols showed potent inhibition (40 $72 \%$ inhibition), particularly of AA-induced edema by topical application ( $2 \mathrm{mg} / \mathrm{ear}$ ). The $\mathrm{ED}_{25}$ or $\mathrm{ED}_{50}$ values of several selected flavonoids are shown in Table 4. All these results indicated that the C-2,3-double bond is essential for in vivo anti-inflammatory activity of flavonoids and the potencies of anti-inflammatory activity depend on the patterns and numbers of hydroxylation(s) on the A/B-ring. 5,7-Hydroxylation on the Aring and 4'-hydroxylation on the B-ring are favorable. The potent inhibitory activities of topically applied flavones/flavonols against AA-induced ear edema suggested that these flavonoids might behave in vivo as COX/LOX inhibitors because topically applied AA converts to PGs and LTs by COX/LOX in the dermal area. This speculation might be supported by the findings that certain flavones/flavonols such as 3-hydroxyflavone, kaempferol, fisetin, and quercetin inhibited COX/LOX as described earlier. Topically applied flavone, which was known as a COX inhibitor (105), was the most active among flavonoids tested in AAinduced ear edema. Nonetheless, it may be concluded that flavonoids are generally far less active anti-inflammatory agents when administered orally, compared to the currently used SAIDs or NSAIDs.

Table 4. Relative anti-inflammatory activity of several flavonoids ${ }^{\mathrm{a}}$

\begin{tabular}{lccccc}
\hline Compounds & \multicolumn{2}{c}{ Croton oil-induced edema } & & \multicolumn{2}{c}{ AA-induced ear edema } \\
\cline { 2 - 3 } \cline { 5 - 6 } & oral $^{\mathrm{b}}$ & topical $^{\mathrm{b}}$ & & oral $^{\mathrm{b}}$ & topical $^{\mathrm{c}}$ \\
\hline hydrocortisone & 0.06 & 0.004 & & 2.1 & 2.0 \\
indomethacin & 0.90 & 0.30 & & 0.09 & 0.08 \\
flavone & - & - & & - & 0.49 \\
apigenin & - & 1.57 & & 4.7 & 2.0 \\
quercetin & 1.95 & 2.08 & & 4.3 & 1.85 \\
biochanin A & 2.78 & 1.67 & & 6.0 & 2.38 \\
\hline
\end{tabular}

${ }^{\mathrm{a}}$ Data from ref. 103 with permission. ${ }^{\mathrm{b}} \mathrm{ED}_{25}, \mathrm{mg} / \mathrm{mouse}$ (oral), $\mathrm{mg} / \mathrm{ear}$ (topical). ${ }^{\mathrm{c}} \mathrm{ED}_{50}, \mathrm{mg} / \mathrm{ear} .{ }^{\mathrm{d}}$ data not available. 
Against rat carrageenan-induced paw edema, several flavanones, flavones, and flavonols showed anti-inflammatory activity by oral administration. The activities of chalcones were very weak (106). From the results, it was suggested that 5,7,4'-methoxyl groups were important and the activity difference might be depending on the pharmacokinetic behavior of each compound. In one important experiment, varieties of flavonoids were examined on cotton pellet granuloma in rats, an animal model of subchronic granulomatic inflammation. When locally injected (25 mg/kg per day), many flavonoids showed inhibition of granulomatic inflammation (107). The highly active ones were flavanones, flavones, and flavonols having 3',4'-dihydroxyl or 3',4'-hydroxyl /methoxyl substitution. The best examples are $5,6,7,3^{\prime}, 4^{\prime}$-pentahydroxyflavone and jacosidin. The flavonols having 2',4'-dihydroxyl moiety (morin) was also active. The results strongly suggested that $3^{\prime}, 4^{\prime}-$ dihydroxyl (catechol type) or 3',4'-hydroxyl/methoxyl (guaiacol type) groups were important for inhibiting granulomatic inflammation. A-ring 5,7-dihydroxyl groups seemed to be favorable, but the effect of glycosylation was not clear. These findings are meaningful because the active flavonoids reported on chronic inflammatory models are limited.

As described above, many flavonoids were found to possess anti-inflammatory activity in vivo. The C-2,3- double bond is important. In vivo activity also depends on the patterns and numbers of hydroxylation/methoxylation. Especially, the A-ring 5,7-dihydroxyl and B-ring 3',4'-catechol groups are important. By oral administration, however, they are generally less active, presumably because of low bioavailability and/or rapid metabolism. Many efforts to find highly active flavonoids having comparable potency with those of the currently used NSAIDs or SAIDs have not been successful. However, flavonoids possess unique cellular mechanisms. Certain flavonoids inhibit eicosanoid generating enzymes as well as inhibit the expression of proinflammatory genes. These effects may be favorable for chronic inflammatory disorders in long-term and safe use. In this respect, some prenylated flavonoids and wogonin may have merits for a clinical trial.

\section{Conclusion}

Flavonoids show anti-inflammatory activity in vitro and in vivo. Several cellular action mechanisms are proposed to explain their anti-inflammatory activity. In addition to antioxidative activity, they inhibit eicosanoid generating enzymes. And certain flavonoids, mainly flavone derivatives, modulate the expression of proinflammatory molecules, at least partly, via inhibition of transcription factor activation. Flavonoids have different

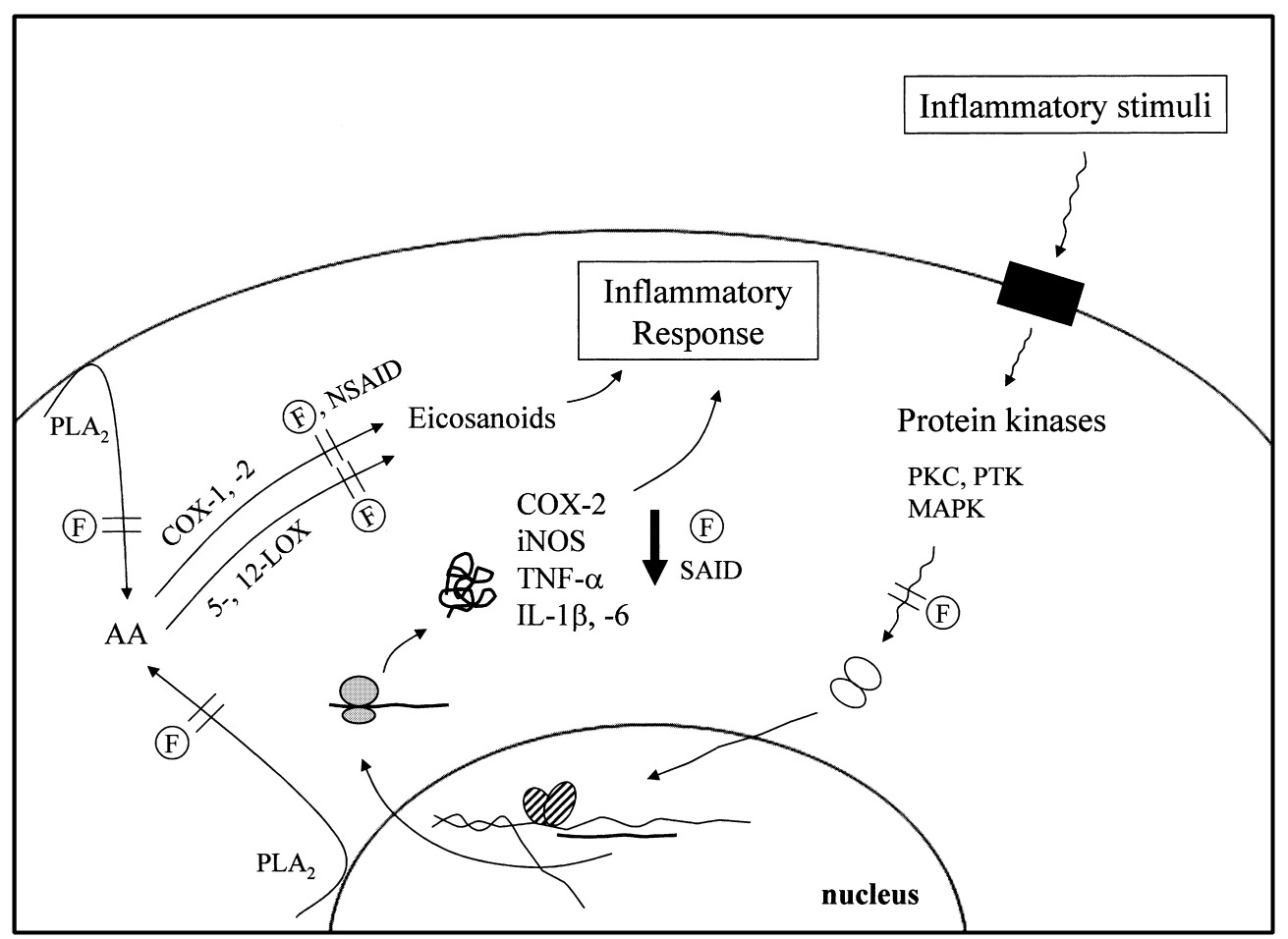

Fig. 4. The proposed action mechanism of flavonoids. Flavonoid (F), nonsteroidal anti-inflammatory drug (NSAID), steroidal anti-inflammatory drug (SAID), "=" and " $\downarrow$ " denote enzyme inhibition and down-regulation of the expression, respectively. 
action mechanisms depending on their chemical structures. Any single mechanism could not explain all of their in vivo activities. They probably have multiple cellular mechanisms acting on multiple sites of cellular machinery, but the most important contributors to antiinflammation by flavonoids seem to be the effect on eicosanoid generating enzymes and the effect on the expression of proinflammatory molecules (Fig. 4). From the experiments to examine various flavonoids on these two effects, the optimum chemical structures are deduced. The important moieties are the C-2,3double bond, A-ring 5,7-hydroxyl groups, and B-ring 4'- or 3',4'-hydroxyl groups. The C-3 hydroxyl group as in flavonols is favorable for LOX inhibition and oral anti-inflammatory activity. Flavones (without C-3hydroxyl group) more strongly down-regulate proinflammatory gene expression. Flavonoids having these chemical structures are apigenin, luteolin, kaempferol, and quercetin. The C- 6 or C- 8 substituted flavones /flavonols such as baicalein and wogonin are also favorable structures. While these flavonoids may not be suitable for acute disorders, they have potentials to treat chronic inflammatory disorders due to unique cellular action mechanisms with less adverse effects. Especially, several prenylated flavonoids show higher activity among the flavonoids examined. They possess potent inhibitory activity against COXs and 5-LOX. Some of them down-regulate proinflammatory gene expression. Although structural-activity relationships could not be obtained, artonins, sanggenons, and sophoraflavanones have merits for further study. It is also necessary to study the effect of flavonoids on recently discovered proinflammatory molecules including COX-3. The continual efforts will provide new insight into the antiinflammatory activity of flavonoids, and eventually lead to development of a new class of anti-inflammatory agent based on the flavonoid molecule.

\section{Acknowledgments}

This work was supported by grant No. R01-2004-00010134-0 from the Basic Research Program of the Korea Science \& Engineering Foundation. Special thanks are given to Drs. Moon Young Heo, Haeil Park, and Hyoung Chun Kim (KNU) for helpful discussions in preparing the manuscript.

\section{References}

1 Havsteen B. Flavonoids, a class of natural products of high pharmacological potency. Biochem Pharmacol. 1983;32:11411148.

2 Middleton E, Kandaswami C, Theoharides TC. The effects of plant flavonoids on mammalian cells: implications for inflammation, heart disease, and cancer. Pharmacol Rev. 2000;52:673751.

3 Bauman J, Bruchhausen FV, Wurm G. Flavonoids and related compounds as inhibitors of arachidonic acid peroxidation. Prostaglandins. 1980;20:627-639.

4 Murakami M, Kudo I. Recent advances in molecular biology and physiology of the prostaglandin $\mathrm{E}_{2}$-biosynthetic pathway. Prog Lipid Res. 2004;43:3-35.

5 Lee T-P, Matteliano ML, Middletone E. Effect of quercetin on human polymorphonuclear leukocyte lysosomal enzyme release and phospholipid metabolism. Life Sci. 1982;31:2765-2774.

6 Lanni C, Becker EL. Inhibition of neutrophil phospholipase $\mathrm{A}_{2}$ by $\mathrm{p}$-bromophenylacyl bromide, nordihydroguaiaretic acid, 5,8,11,14-eicosatetrayenoic acid and quercetin. Int Archs Allergy Appl Immun. 1985;76:214-217.

7 Lindahl M, Tagesson C. Selective inhibition of group II phospholipase $A_{2}$ by quercetin. Inflammation. 1993;17:573-582.

8 Welton AF, Tobias LD, Fiedler-Nagy C, Anderson W, Hope W, Meyer K, et al. Effect of flavonoids on arachidonic acid metabolism. In: Cody V, Middleton E, Harborne JB, editors. Plant flavonoids in biology and medicine. New York: Alan R. Liss; 1986. p. 231-242.

9 Gil B, Sanz MJ, Terencio MC, Ferrandiz ML, Bustos G., Paya $\mathrm{M}$, et al. Effects of flavonoids on Naja naja and human recombinant synovial phospholipase $\mathrm{A}_{2}$ and inflammatory responses in mice. Life Sci. 1994;54:PL333-PL338.

10 Chang HW, Baek SH, Chung KW, Son KH, Kim HP, Kang $\mathrm{SS}$. Inactivation of phospholipase $\mathrm{A}_{2}$ by naturally occurring biflavonoid, ochnaflavone. Biochem Biophys Res Commun. 1994;205:843-849.

11 Gil B, Sanz MJ, Terencio MC, Gunasegaran R, Paya M, Alcaraz MJ. Morelloflavone, a novel biflavonoid inhibitor of human secretory phospholipase $\mathrm{A}_{2}$ with anti-inflammatory activity. Biochem Pharmacol. 1997;53:733-740.

12 Baek SH, Yun SS, Kwon TK, Kim JR, Chang HW, Kwak JY, et al. The effects of two new antagonists of secretory $\mathrm{PLA}_{2}$ on TNF- $\alpha$, iNOS, and COX-2 expression in activated macrophages. Shock. 1999;12:473-478.

13 Kim HP, Pham HT, Ziboh VA. Flavonoids differentially inhibit guinea pig epidermal cytosolic phospholipase $\mathrm{A}_{2}$. Prostaglandins Leukot Essent Fatty Acids. 2001;65:281-286.

14 Lee SJ, Son KH, Chang HW, Kang SS, Kim HP. Inhibition of arachidonate release from rat peritoneal macrophages by biflavonoids. Arch Pharm Res. 1997;20:533-538.

15 Kwak W-J, Moon TC, Lin CX, Rhyn HG, Jung H, Lee E, et al. Papyriflavonol A from Broussonetia papyrifera inhibits the passive cutaneous anaphylaxis reaction and has a secretory phospholipase $\mathrm{A}_{2}$-inhibitory activity. Biol Pharm Bull. 2003;26: 299-302.

16 Simmons DL. Variants of cyclooxygenase-1 and their roles in medicine. Thromb Res. 2003;110:265-268.

17 Needleman P, Isakson P. The discovery and function of COX-2. J Rheumatol. 1997;24 Suppl 49:6-8.

18 McMurray RW, Hardy KJ. COX-2 inhibitors: today and tomorrow. Am J Med Sci. 2002;323:181-189.

19 Crofford LJ, Oates JC, McCune WJ, Gupta S, Kaplan MJ, Castella-Lawson F, et al. Thrombosis in patients with connective tissue diseases treated with specific cyclooxygenase 2 inhibitors. A report of four cases. Arthritis Rheum. 2000;43:1891-1896. 
20 Landolfi R, Mower RL, Steiner M. Modification of platelet function and arachidonic acid metabolism by bioflavonoids. structure-activity relations. Biochem Pharmacol. 1984;33:15251530 .

21 Nakadate T, Aizu E, Yamamoto S, Kato R. Effects of chalcone derivatives on lipoxygenase and cyclooxygenase activities of mouse epidermis. Prostaglandins. 1985;3:357-368.

22 Alcaraz MJ, Hoult JRS. Actions of flavonoids and the novel anti-inflammatory flavone, hypolaetin-8-glucoside, on prostaglandin biosynthesis and inactivation. Biochem Pharmacol. 1985;34:2477-2482.

23 Ferrandiz ML, Ramachandran Nair AG, Alcaraz MJ. Inhibition of sheep platelet arachidonate metabolism by flavonoids from Spanish and Indian medicinal herbs. Pharmazie. 1990;45:206208.

24 Laughton MJ, Evans PJ, Moroney MA, Hoult JRS, Halliwell B. Inhibition of mammalian 5-lipoxygenase and cyclooxygenase by flavonoids and phenolic dietary additives. Biochem Pharmacol. 1991;42:1673-1681.

25 You KM, Jong H, Kim HP. Inhibition of cyclooxygenase /lipoxygenase from human platelets by polyhydroxylated /methoxylated flavonoids isolated from the several medicinal plants. Arch Pharm Res. 1999;22:18-24.

26 Kimura Y, Okuda H, Nomura T, Fukai T, Arichi S. Effects of flavonoids and related compounds from mulberry tree on archidonate metabolism in rat platelet homogenates. Chem Pharm Bull. 1986;34:1223-1227.

27 Kimura Y, Okuda H, Nomura T, Fukai T, Arichi S. Effects of phenolic constituents from the mulberry tree on arachidonate metabolism in rat platelets. J Nat Prod. 1986;49:639-644.

28 Lin CN, Lu CM, Lin HC, Fang SC, Shieh BJ, Hsu MF, et al. Novel antiplatelet constituents from Formosan Moraceous plants. J Nat Prod. 1996;59:834-838.

29 Chi YS, Jong H, Son KH, Chang HW, Kang SS, Kim HP. Effects of naturally occurring prenylated flavonoids on arachidonic acid metabolizing enzymes: cylooxygenases and lipoxygenases. Biochem Pharmacol. 2001;62:1185-1191.

30 Kim HP, Indu M, Iversen L, Ziboh VA. Effects of naturallyoccurring flavonoids and biflavonoids on epidermal cyclooxygenase and lipoxygenase from guinea-pigs. Prostaglandins Leukot Essent Fatty Acids. 1998;58:17-24.

31 Noreen Y, Serrano G, Perera P, Bohlin L. Flavan-3-ols isolated from some medicinal plants inhibiting COX-1 and COX-2 catalysed prostaglandin biosynthesis. Planta Med. 1998;64:520524.

32 Jang DS, Cuendet M, Hawthorne ME, Kardono LBS, Kawanishi $\mathrm{K}$, Fong HHS, et al. Prenylated flavonoids of the leaves of Macaranga conifera with inhibitory activity against cyclooxygenase-2. Phytochemistry. 2002;61:867-872.

33 Likhiwitayawuid K, Sawasdee K, Kirtikara K. Flavonoids and stilbenoids with COX-1 and COX-2 inhibitory activity from Dracaena loureiri. Planta Med. 2002;68:841-843.

34 Seeram NP, Zhang Y, Nair MG. Inhibition of proliferation of human cancer cells and cyclooxygenase enzymes by anthocyanidins and catechins. Nutr Cancer. 2003;46:101-106.

35 Yoshimoto T, Furukawa M, Yamamoto S, Horie T, WatanabeKohno S. Flavonoids: Potent inhibitors of arachidonate 5-lipoxygenase. Biochem Biophys Res Commun. 1983;116:612-618.

36 Horie T, Tsukayama M, Kurai N, Yokoyama C, Furukawa M, Yoshimoto T, et al. Synthesis of 5,6,7 and 5,7,8-trioxygenated 3',4'-dihydroxyflavones having alkoxy groups and their inhibitory activities against arachidonate 5-lipoxygenase. J Med Chem. 1986;29:2256-2262.

37 Nakadate T, Yamamoto S, Aizu E, Kato R. Effects of flavonoids and antioxidants on 12-O-tetradecanoylphorbol 13-acetate induced epidermal ornithine decarboxylase induction and tumor promotion in relation to lipoxygenase inhibition by these compounds. Gann. 1984;75:214-222.

38 Reddy GR, Ueda N, Hada T, Sackeyfio AC, Yamamoto S, Hana Y, et al. A prenylatedflavone, artonin E, as arachidonate 5lipoxygenase inhibitor. Biochem Pharmacol. 1991;41:115-118.

39 Moncada S, Palmer RMJ, Higgs EA. Nitric oxide: physiology, pathophysiology, and pharmacology. Pharmacol Rev. 1991;43: 109-142.

40 Nathan C. Nitric oxide as a secretory product of mammalian cells. FASEB J. 1992;6:3051-3064.

41 Chiesi M, Schwaller R. Inhibition of constitutive endothelial NO synthase activity by tannin and quercetin. Biochem Pharmacol. 1995;49:495-501.

42 Benito S, Lopez D, Saiz MP, Buxaderas S, Sanchez J, Puigparellada $\mathrm{P}$, et al. A flavonoid-rich diet increases nitric oxide production in rat aorta. Br J Pharmacol. 2002;135:910-916.

43 Cheon BS, Kim YH, Son KH, Chang HW, Kang SS, Kim HP. Effects of prenylated flavonoids and biflavonoids on lipopolysaccharide-induced nitric oxide production from the mouse macrophage cell line, RAW 264.7. Planta Med. 2000;66:596-600.

44 Krol W, Czuba ZP, Threadgill MD, Cunningham BD, Pietse G. Inhibition of nitric oxide (NO) production in murine macrophages by flavones. Biochem Pharmacol. 1995;50:1031-1035.

45 Sadowska-Krowicka H, Mannick EE, Oliver PD, Sandoval M, Zhang XJ, Eloby-Childess S, et al. Genistein and gut inflammation: Role of nitric oxide. Proc Soc Exp Biol Med. 1998;217:351-357.

46 Soliman KFA, Mazzio EA. In vitro attenuation of nitric oxide production in C6 astrocyte cell culture by various dietary compounds. Proc Soc Exp Biol Med. 1998;218:390-397.

47 Kim HK, Cheon BS, Kim YH, Kim SY, Kim HP. Effects of naturally occurring flavonoids on nitric oxide production in the macrophage cell line RAW 264.7 and their structural-activity relationships. Biochem Pharmacol. 1999;58:759-765.

48 Liang YC, Huang YT, Tsai SH, Lin-Shiau SY, Chen CF, Lin JK. Suppression of inducible cyclooxygenase and inducible nitric oxide synthase by apigenin and related flavonoids in mouse macrophages. Carcinogenesis. 1999;20:1945-1952.

49 Chan MM, Fong D, Ho CT, Huang HT. Inhibition of inducible nitric oxide synthase gene expression and enzyme activity by epigallocatechin gallate, a natural product from green tea. Biochem Pharmacol. 1997;54:1281-1286.

50 Murakami A, Nakamura Y, Torikai K, Tanaka T, Koshiba T, Koshimizu K, et al. Inhibitory effect of citrus nobiletin on phorbol ester-induced skin inflammation, oxidative stress, and tumor promotion in mice. Cancer Res. 2000;60:5059-5066.

51 Chen YC, Yang LL, Lee TJF. Oroxylin A inhibition of lipopolysaccharide-induced iNOS and COX-2 gene expression via suppression of nuclear factor- $\kappa \mathrm{B}$ activation. Biochem Pharmacol. 2000;59:1445-1457.

52 Chi YS, Cheon BS, Kim HP. Effect of wogonin, a plant flavone from Scutellaria radix, on the suppression of cyclooxygenase and the induction of inducible nitric oxide synthase in 
lipopolysaccharide-treated RAW 264.7 cells. Biochem Pharmacol. 2001;61:1195-1203.

53 Raso GM, Meli R, Di Carlo G, Pacillio M, Di Carlo R. Inhibiton of inducible nitric oxide synthase and cyclooxygenase-2 expression by flavonoids in macrophage J774A.1. Life Sci. 2001;68:921-931.

$54 \mathrm{Kim}$ H, Kim YS, Kim SY, Suk K. The plant flavonoid wogonin suppresses death of activated C6 rat glial cells by inhibiting nitric oxide production. Neurosci Lett. 2001;309:67-71.

55 Shen SC, Lee WR, Lin HY, Huang HC, Ko CH, Yang LL, et al. In vitro and in vivo inhibitory activities of rutin, wogonin, and quercetin on lipopolysaccharide-induced nitric oxide and prostaglandin $\mathrm{E}_{2}$ production. Eur J Pharmacol. 2002;446:187194.

56 Singh R, Ahmed S, Islam N, Goldberg VM, Haqqi TM. Epigallocatechin-3-gallate inhibits interleukin-1 $\beta$-induced expression of nitric oxide synthase and production of nitric oxide in human chondrocytes. Suppression of nuclear factor $\kappa \mathrm{B}$ by degradation of the inhibitor of nuclear factor $\kappa \mathrm{B}$. J Rheumatol. 2002;46:2079-2086.

57 Takahashi T, Takasuka N, Ligo M, Baba M, Nishino H, Tsuda $\mathrm{H}$, et al. Isoliquilitigenin, a flavonoid from licorice, reduces prostaglandin $\mathrm{E}_{2}$ and nitric oxide, causes apoptosis, and suppresses aberrant crypt foci development. Cancer Sci. 2004;95:448-453.

58 Kim YP, Yamada M, Lim SS, Lee SH, Ryu N, Shin KH, et al. Inhibition of tectorigenin and tectoridin of prostaglandin $\mathrm{E}_{2}$ production and cyclooxygenase-2 induction in rat peritoneal macrophages. Biochim Biophys Acta. 1999;1438:399-407.

59 Mutoh M, Takahashi M, Fukuda K, Komatsu H, Enya T, Matsushima-Hibiya Y, et al. Suppression by flavonoids of cyclooxygenase-2 promotor-dependent transcriptional activity in colon cancer cells: Structural-activity relationship. Jpn J Cancer Res. 2000;91:686-691.

60 Wakabayashi I, Yasui K. Wogonin inhibits inducible prostaglandin $\mathrm{E}_{2}$ production in macrophages. Eur $\mathrm{J}$ Pharmacol. 2000;406:477-481.

61 Wenzel U, Kuntz S, Brendel MD, Daniel H. Dietary flavone is a potent apoptosis inducer in human colon carcinoma cells. Cancer Res. 2000;60:3823-3831.

62 Banerjee T, Valacchi G, Ziboh VA, van der Vliet A. Inhibition of TNF $\alpha$-induced cyclooxygenase- 2 expression by amentoflavone through suppression of NF- $\kappa$ B activation in A549 cells. Mol Cell Biochem. 2002;238:105-110.

63 Lin N, Sato T, Takayama Y, Mimaki Y, Sashida Y, Yano M, et al. Novel anti-inflammatory actions of nobiletin, a citrus polymethoxy flavonoid, on human synovial fibroblasts and mouse macrophages. Biochem Pharmacol. 2003;65:2065-2071.

64 Bingham CO III. The pathogenesis of rheumatoid arthritis: pivotal cytokines involved in bone degradation and inflammation. J Rheumatol. 2002;29 Suppl. 65:3-9.

65 Geng Y, Zhang B, Lotz M. Protein tyrosine kinase activation is required for lipopolysaccharide induction of cytokines in human blood monocytes. J Immunol. 1993;151:6692-6700.

66 Cho JY, Kim PS, Park J, Yoo ES, Baik KU, Kim Y-K, et al. Inhibitor of tumor necrosis factor- $\alpha$ production in lipopolysaccharide-stimulated RAW 264.7 cells from Amorpha fruticosa. J Ethnopharmacol. 2000;70:127-133.

67 Krakauer T, Li BQ, Young HA. The flavonoid baicalin inhibits superantigen-induced inflammatory cytokines and chemokines.
FEBS Lett. 2001:500:52-55.

68 Nakajima T, Imanishi M, Yamamoto K, Cyong JC, Hirai K. Inhibitory effect of baicalein, a flavonoid in Scutellaria root, on eotaxin production by human dermal fibroblasts. Planta Med. 2001;67:132-135.

69 Higa S, Hirano T, Kotani M, Matsumoto M, Fujita A, Suemura $\mathrm{M}$, et al. Fisetin, a flavonol, inhibits $\mathrm{T}_{\mathrm{H}} 2$-type cytokine production by activated human basophils. J Allergy Clin Immunol. 2003;111:1299-1306.

70 Gerritsen ME, Carley WW, Ranges GE, Shen CP, Phan SA, Ligon GF, et al. Flavonoids inhibit cytokine-induced endothelial cell adhesion protein gene expression. Am J Pathol. 1995; 147:278-292.

71 Chung CP, Park JB, Bae KW. Pharmacological effects of methanolic extract from the root of Scutellaria baicalensis and its flavonoids on human gingival fibroblast. Planta Med. 1995;61:150-153.

72 Wadsworth TL, McDonald TL, Koop DR. Effects of Ginkgo biloba extract (EGb 761) and quercetin on lipopolysaccharideinduced signaling pathways involved in the release of tumor necrosis factor- $\alpha$. Biochem Pharmacol. 2001;62:963-974.

73 Dien MV, Takahashi K, Mu MM, Koide N, Sugiyama T, Mori I, et al. Protective effect of wogonin on endotoxin-induced lethal shock in D-galactosamine-sensitized mice. Microbiol Immunol. 2001:45:751-756.

74 Xagorari A, Roussos C, Papapetropoulos A. Inhibition of LPSstimulated pathways in macrophages by the flavonoid luteolin. Br J Pharmacol. 2002;136:1058-1064.

75 Cho SY, Park SJ, Kwon MJ, Jeong TS, Bok SH, Cho, WY, et al. Quercetin suppresses proinflammatory cytokines production through MAP kinases and NF- $\kappa \mathrm{B}$ pathway in lipopolysaccharide-stimulated macrophage. Mol Cell Biochem. 2003; 243:153-160.

76 Nakamura N, Hayasaka S, Zhang XY, Nagaki Y, Matsumoto M, Hayasaka $Y$, et al. Effects of baicalin, baicalein and wogonin on interleukin- 6 and interleukin- 8 expression, and nuclear factor$\kappa \mathrm{B}$ binding activities induced by interleukin- $1 \beta$ in human retinal pigmant epithelial cell line. Exp Eye Res. 2003;77:195-202.

77 Ferriola PC, Cody V, Middleton E. Protein kinase C inhibition by plant flavonoids. Kinetic mechanisms and structural-activity relationships. Biochem Pharmacol. 1989;38:1617-1624.

78 Chang CJ, Geahlen RL. Protein-tyrosine kinase inhibition: mechanism-based discovery of antitumor agents. J Nat Prod. 1992;55:1529-1590.

79 Weinstein SL, Sanghera JS, Lemke K, DeFranco AL, Pelech SL. Bacterial lipopolysaccharide induces tyrosine phosphorylation and activation of mitogen-activated protein kinases in macrophages. J Biol Chem. 1992;267:14955-14962.

80 Wadsworth TL, Koop DR. Effects of Ginkgo biloba extract (EGb 761) and quercetin on lipopolysaccharide-induced release of nitric oxide. Chem Biol Interact. 2001;137:43-58.

81 Chang YL, Shen JJ, Wung BS, Chen JJ, Wang DL. Chinese herbal remedy wogonin inhibits monocyte chemotactic protein-1 gene expression in human endothelial cells. Mol Pharmacol. 2001;60:507-513.

82 Kim SH, Shin KJ, Kim D, Kim YH, Han MS, Lee TG, et al. Luteolin inhibits the nuclear factor- $\kappa \mathrm{B}$ transcriptional activity in Rat-1 fibroblasts. Biochem Pharmacol. 2003;66:955-963.

83 Liang YC, Tsai SH, Tsai DC, Lin-Shiau SY, Lin JK. Suppression of inducible cyclooxygenase and nitric oxide synthase 
through activation of peroxisome proliferator-activated receptor$\gamma$ by flavonoids in mouse macrophages. FEBS Lett. 2001; 496:12-18.

84 Kazi A, Daniel KG, Smith DM, Kumar NB, Dou QP. Inhibition of the proteasome activity, a novel mechanism associated with the tumor cell apoptosis-inducing ability of genistein. Biochem Pharmacol. 2003;66:956-976.

85 Takahashi K, Morikawa A, Kato Y, Sugiyama T, Koide N, $\mathrm{Mu} \mathrm{MM}$, et al. Flavonoids protect mice from two types of lethal shock induced by endotoxin. FEMS Immunol Med Microbiol. 2001;31:29-33.

86 Park BK, Heo MY, Park H, Kim HP. Inhibition of TPA-induced cyclooxygenase-2 and skin inflammation in mice by wogonin, a plant flavone from Scutellaria radix. Eur $\mathrm{J}$ Pharmacol. 2001;425:153-157.

87 Kwak WJ, Han CK, Son KH, Chang HW, Kang SS, Park BK, et al. Effects of ginkgetin from Ginkgo biloba leaves on cyclooxygenases and in vivo skin inflammation. Planta Med. 2002; 68:316-321.

88 Kotanidou A, Xagorari A, Bagli E, Kitsanta P, Fotsis T, Papapetropoulos A, et al. Luteolin reduces lipopolysaccharideinduced lethal toxicity and expression of proinflammatory molecules in mice. Am J Respir Crit Care Med. 2002;165:818823.

89 Ueda H, Yamazaki C, Yamazaki M. A hydroxyl group of flavonoids affects oral anti-inflammatory activity and inhibition of systemic tumor necrosis factor- $\alpha$ production. Biosci Biotechnol Biochem. 2004;68:119-125.

90 Morikawa K, Nonaka M, Narahara M, Torii I, Kawaguchi K, Yoshikawa $\mathrm{T}$, et al. Inhibitory effect of quercetin on carrageenan-induced inflammation in rats. Life Sci. 2003;74:709-721.

91 Kubo M, Matsuda H, Tanaka M, Kimura Y, Okuda H, Higashino M, et al. Studies on Scutellaria radix. VII. Antiarthritic and anti-inflammatory actions of methanolic extracts and flavonoid components from Scutellaria radix. Chem Pharm Bull. 1984;32:2724-2729.

92 Wakabayashi I. Inhibitory effects of baicalein and wogonin on lipopolysaccharide-induced nitric oxide production in macrophages. Pharmacol Toxicol. 1999;84:288-291.

93 Chiu JH, Lay IS, Su MY, Chiu HL, Chiu AC, Lui WY, et al. Tumor necrosis factor-producing activity of wogonin in RAW 264.7 murine macrophage cell line. Planta Med. 2002;68:10361039.

94 Lee H, Kim YO, Kim H, Kim SY, Noh HS, Kang SS, et al. Flavonoid wogonin from medicinal herb is neuroprotective by inhibiting inflammatory activation of microglia. FASEB J. 2003;17:1943-1944.
95 Chi YS, Lim H, Park H, Kim HP. Effect of wogonin, a plant flavone from Scutellaria radix, on skin inflammation: in vivo regulation of inflammation-associated gene expression. Biochem Pharmacol. 2003;66:1271-1278.

96 Lim H, Park H, Kim HP. Inhibition of contact dermatitis in animal models and suppression of proinflammatory gene expression by topically applied flavonoid, wogonin. Arch Pharm Res. 2004;27:442-448.

97 Kuhnau J. The flavonoids: A class of semi-essential food components: their role in human nutrition. World Rev Nutr Diet. 1976;24:117-191.

98 Hertog MGL, Hollman PCH, Katan MB. Content of potentially anticarcinogenic flavonoids of 28 vegetables and 9 fruits commonly consumed in the Netherlands. J Agric Food Chem. 1992;40:2379-2383.

99 Hertog MGL, Feskens EJM, Hollman PCH, Katan MB, Kromhout D. Dietary antioxidant flavonoids and risk of coronary heart disease: the Zutphen elderly study. Lancet. 1993; 342:1007-1011.

100 Gabor M. Anti-inflammatory and antiallergy properties of flavonoids. In: Cody V, Middleton E, Harborne JB, editors. Plant flavonoids in biology and medicine. New York: Alan R. Liss; 1986. p. 471-480.

101 Lewis DA. Flavonoids. In: Lewis DA, editor. Anti-inflammatory drugs from plant and marine sources, Agents and Actions Suppl. Vol. 27, Basel: Berkhauser Verlag; 1989. p. 137-165.

102 Yasukawa K, Takido M, Takeuchi M, Nakagawa S. Effect of chemical constituents from plants on 12-O-tetradecanoylphorbol-13-acetate-induced inflammation in mice. Chem Pharm Bull (Tokyo). 1989;37:1071-1073.

103 Kim HK, Namgoong SY, Kim HP. Antiinflammatory activity of flavonoids: Mouse ear edema inhibition. Arch Pharm Res. 1993;16:18-24.

104 Lee SJ, Son KH, Chang HW, Do JC, Jung KY, Kang SS, et al. Antiinflammatory activity of naturally occurring flavone and flavonol derivatives. Arch Pharm Res. 1993;16:25-28.

105 Welton AF, Hurley J, Willi P. Flavonoids and arachidonic acid metabolism. In: Cody V, Middleton E, Harborne JB, Beretz A, editors. Plant flavonoids in biology and medicine II. New York: Alan R. Liss; 1988. p. 301-312.

106 Panthong A, Kanjanapothi D, Tuntiwachwuttkul P, Pancharoen O, Reutrakul V. Antiinflammatory activity of flavonoids. Phytomedicine. 1994;1:141-144.

107 Pelzer LE, Guardia T, Osvaldo Juarez A, Guerreiro E. Acute and chronic anti-inflammatory effects of plant flavonoids. Farmaco. 1998;53:421-424. 